\title{
Starch digestibility and predicted glycemic index of fried sweet potato cultivars
}

\section{Amaka Odenigbo ${ }^{1}$, Jamshid Rahimi $^{1}$, Michael Ngadi ${ }^{1}$, Somaia Amer $^{2}$, Arif Mustafa ${ }^{2}$}

${ }^{1}$ Department of Bioresource Engineering, McGill University, 21111 Lakeshore Road, SainteAnne-de-Bellevue, Quebec, H9X 3V9 Canada; ${ }^{2}$ Department of Animal Science, McGill University, 21111 Lakeshore Road, Sainte-Anne-de-Bellevue, Quebec, H9X 3V9 Canada

Corresponding author: Michael Ngadi, Associate Professor, Department of Bioresource Engineering, McGill University, 21111 Lakeshore Road, Sainte-Anne-de-Bellevue, Quebec, H9X 3V9 Canada.

Submission date: May 20, 2012, Acceptance date: July 23, 2012; Publication date: July 28, 2012

\begin{abstract}
Background: Sweet potato (Ipomoea batatas L.) is a very rich source of starch. There is increased interest in starch digestibility and the prevention and management of metabolic diseases.
\end{abstract}

Objective: The aim of this study was to evaluate the levels of starch fractions and predicted glycemic index of different cultivars of sweet potato.

Material and Method: French fries produced from five cultivars of sweet potato ('Ginseng Red', 'Beauregard', 'White Travis', 'Georgia Jet clone \#2010' and 'Georgia Jet') were used. The level of total starch (TS), resistant starch (RS), digestible starch (DS), and starch digestion index starch digestion index in the samples were evaluated. In vitro starch hydrolysis at 30, 90, and 120 min were determined enzymatically for calculation of rapidly digestible starch (RDS), predicted glycemic index (pGI) and slowly digestible starch (SDS) respectively.

Results: The RS content in all samples had an inversely significant correlation with pGI (0.52; $\mathrm{P}<0.05)$ while RDS had positive and significant influence on both $\mathrm{pGI}(\mathrm{r}=0.55 ; \mathrm{P}<0.05)$ and SDI ( $\mathrm{r}=0.94$; $\mathrm{P}<0.01)$. 'White Travis' and 'Ginseng Red' had higher levels of beneficial starch fractions (RS and SDS) with low pGI and starch digestion Index (SDI), despite their higher TS content. Generally, all the cultivars had products with low to moderate GI values.

Conclusion: The glycemic index of these food products highlights the health promoting characteristics of sweet potato cultivars.

Keywords: Sweet potato, Ipomoea batatas L, French fries, in vitro starch digestibility, glycemic index, resistant starch 


\section{INTRODUCTION}

Sweet potato (Ipomoea batatas L.) root is an important food crop and a good source of starch and energy. The predominant fraction of its dry matter is starch content. Ravindran et al. [1] reported an average starch content of $72.1 \mathrm{~g} / 100 \mathrm{~g}$ on dry basis in a study of 16 various sweet potato cultivars.

Nutritionally, starch is classified based on its rate of digestion into rapidly digestible starch, slowly digestible starch, and resistant starch [2]. Starch digestion rate and its consequent glycemic impact is greatly influenced by the food composition such as resistant starch content, phosphorylated starch, phytonutrients, dietary fibre, protein, and fat content $[3,4]$. Similarly, methods of food processing and cultivar affect the glycemic index of sweet potato [5,6]. The heat generated during cooking breaks down starch granules in the sweet potato facilitating hydrolysis by pancreatic $\alpha$-amylase, which consequently increases the glycemic index of cooked sweet potato. Converesely, raw food stores its starch in compact granules which digest poorly [6]. Mahmood et al. [7] reported that the resistant starch value of processed potato is lower compared to the resistant starch content in raw potato. However, frying and boiling methods of food processing result in higher RS and lower glycemic index (GI) compared to roasting and baking [8].

Resistant starch (RS) is an important measurement to characterize starch digestibility. It has been defined as the starch fraction in foods which is highly resistant to digestion by digestive enzymes [9]. Current protocol for RS analysis involved a $16 \mathrm{hr}$ enzymatic incubation for digestible starch hydrolysis before the treatment and hydrolysis of RS pellet [4, $10]$.

Glycemic index (GI) is the measure of immediate effect on blood glucose level after food consumption. It is expressed as a percentage of incremental glucose area under the curve (iAUC) of a test food with reference to a standard food (white bread or glucose) containing the same available carbohydrates [11]. The experimental time, financial, and ethical burden involved in the evaluation of glycemic index in human subjects led to in vitro studies on starch digestibility $[2,10]$.

Foods are classified into three categories of glycemic index: low GI; $\leq 55$, medium GI = 55-69, and high GI; $\geq 70$ [6]. The low glycemic index foods are beneficial in management of disease conditions such as diabetes mellitus and cardiovascular disease [12, 13].

Sweet potato has been identified as one of the beneficial foods for improving glycemic control particularly among diabetic patients $[8,14,15]$. Most of the sweet potato cultivars consumed in Canada are imported from USA. 'Beauregard' is the current mainstay cultivar in the United States sweet potato industry and 'Travis' is an early maturing cultivar [16]. However, Ginseng Red (GR), Beauregard (B), White Travis (WT), Georgia Jet (GJ) and Georgia Jet clone \#2010 (GJ \#2010) are five grown cultivars at the Horticultural Research Centre of Macdonald Campus of McGill University, Canada. A previous study on glycemic response of Beauregard cultivar was subjected to only baking, dehydration, steaming, and microwave cooking [6]. Therefore, this study aimed to characterize the starch fractions and glycemic index of fried products from the five cultivars, namely: Ginseng Red (GR), Beauregard (B), White Travis (WT), Georgia Jet (GJ) and Georgia Jet clone \#2010 (GJ \#2010) grown at the Horticultural Research Centre, McGill University.

\section{MATERIALS AND METHODS}

\subsection{Samples}


Five different cultivars of sweet potato; Ginseng Red (GR), Beauregard (B), White Travis (WT), Georgia Jet (GJ) and Georgia Jet clone \#2010 (GJ \#2010) were used for this study.

\subsection{Processing methods}

The tubers were manually peeled with a hand peeler and cut into discs using a slicer. A kitchen deep fat fryer (T-FAL, Model 6197, Scarborough, Ontario, Canada) was used for frying at $180 \pm 2^{\circ} \mathrm{C}$ for $5 \mathrm{~min}$. Canola oil was used and all experiments were performed in triplicate.

\section{Sample Analysis:}

Chemical analysis: Standard methods were used for determination of moisture, ash, crude protein and fat in the samples [17]. Each sample was analysed in triplicate.

Resistant starch (RS): Resistant starch was determined using a kit assay (K-RSTAR, Megazyme Bray, Co. Wicklow, Ireland). Defatted and milled, freeze dried samples $(100 \pm 0.5 \mathrm{mg})$ were incubated with pancreatic $\alpha$-amylase $(10 \mathrm{mg} / \mathrm{ml})$ solution containing amyloglucosidase (AMG) for $16 \mathrm{~h}$ at $37^{\circ} \mathrm{C}$ with constant shaking. After hydrolysis, samples were washed thrice with ethanol $(99 \% \mathrm{v} / \mathrm{v}$ and $50 \%$ ethanol). The separated pellet from supernatant was further digested with $2 \mathrm{M} \mathrm{KOH}$. Digested pellet and supernatant were separately incubated with AMG. Glucose released was measured using a glucose oxidaseperoxidase (GOPOD) reagent kit (K-GLOX, Megazyme Bray, Co. Wicklow, Ireland) by absorbance at $510 \mathrm{~nm}$ against the reagent blank. The glucose content of the supernatant and digested pellet were used in calculation of digestible starch (DS) and Resistant Starch (RS) respectively by applying the factor of 0.9. Total starch (TS) was then derived as the sum of DS and RS.

In vitro starch digestion: A modified in vitro method based on the procedure of Goñi et al. [10] was adopted. The freeze dried sample $(50 \pm 0.5 \mathrm{mg})$ portions were incubated with $10 \mathrm{ml}$ $\mathrm{HCl}-\mathrm{KCl}$ buffer $\left(\mathrm{pH} \mathrm{1.5)}\right.$ and $20 \mathrm{mg}$ pepsin at $40^{\circ} \mathrm{C}$ for $1 \mathrm{~h}$ with constant shaking. The $\mathrm{pH}$ was raised with the addition of $200 \mu \mathrm{l}$ pancreatic $\alpha$-amylase solution $(1.5 \mathrm{mg} / 10 \mathrm{ml}$ phosphate buffer) and incubated at $37^{\circ} \mathrm{C}$ for $45 \mathrm{~min}$. The enzyme reaction was stopped with $70 \mu \mathrm{l} \mathrm{Na} \mathrm{CO}_{3}$ solution and samples diluted to $25 \mathrm{ml}$ with tris-maleate buffer ( $\mathrm{pH}$ 6.9). Five (5) $\mathrm{ml}$ of pancreatic $\alpha$-amylase solution ( $1 \mathrm{mg} / 5 \mathrm{ml}$ tris-maleate buffer) was then added to the sample and incubated at $37^{\circ} \mathrm{C}$ with constant shaking. Aliquots (duplicate) of $1 \mathrm{ml}$ were taken at 30,90, and $120 \mathrm{~min}$ from the samples and placed into boiling water with vigorous shaking for $5 \mathrm{~min}$ to inactivate the enzyme reaction. Afterward, samples were refrigerated $\left(4^{\circ} \mathrm{C}\right)$ until the end of incubation time (120 min).

Aliquots were treated with $3 \mathrm{ml}$ of $0.4 \mathrm{M}$ sodium acetate buffer $(\mathrm{pH} 4.75)$ and $60 \mu \mathrm{l}$ of AMG $(3,300 \mathrm{U} / \mathrm{ml})$ then incubated at $60^{\circ} \mathrm{C}$ for 45 min with constant shaking.

The glucose released was measured using a glucose oxidase-peroxidase (GOPOD) reagent kit (K-GLOX, Megazyme Bray, Co. Wicklow, Ireland) by absorbance at $510 \mathrm{~nm}$ against the reagent blank. This was then converted into starch by multiplying the amount of glucose by 0.9 .

The rate of starch digestion was expressed as a percentage of the total starch hydrolysed at different times (30,90, $120 \mathrm{~min})$. The 30 and $120 \mathrm{~min}$ hydrolysis represented the rapidly digestible starch (RDS) and slowly digestible starch (SDS) respectively [4]. The 
90 min hydrolysis according to Goñi et al. [10] was used in calculation of predicted glycemic index $\left[\mathrm{pGI}=39.21+0.803\left(\mathrm{H}_{90}\right)\right]$.

The equation by Rashmi and Urooj [18] was adopted for calculation of starch digestion Index (SDI): = RDS/TS X100

\section{Statistical analysis:}

Data were expressed as mean values of three replicate measurements. Variation in levels of starch fractions, digestibility, and pGI among cultivars were determined by a one way analysis of variance (ANOVA) followed by Duncan's multiple range test $(P<0.05)$. Relationship between study parameters were calculated with Pearson correlation coefficients (I). Statistical software used was SAS version 4.3 (SAS Institute Inc., 2010, Cary, NC, USA).

\section{RESULTS AND DISCUSSION}

The proximate composition varied significantly $(\mathrm{P}<0.05)$ among these sweet potato cultivars (Table1). Crude protein content ranged between 2.88 to $7.74 \mathrm{~g} / 100 \mathrm{~g}$ dry weight. This range of crude protein composition is similar to the range of $2.95-7.19 \mathrm{~g} / 100 \mathrm{~g}$ dry weight observed in a study of 16 sweet potato cultivars grown in Sri Lanka [1]. Cultivar WT (7.74 g/100 g) had the highest crude protein content $(\mathrm{P}<0.05)$, while a significant low crude protein content was found in cultivars GJ \#2010 and GJ. This variation in protein composition indicates the potential of certain cultivars as good source of protein. This agrees with the finding of Aina $e t$ al. [19] that some cultivars contained significantly higher protein values than others.

Table 1: Chemical composition of French fries produced with different cultivars of sweet potato $(\mathrm{g} / 100 \mathrm{~g}$ dry basis).

\begin{tabular}{clllll}
\hline Cultivars & Moisture $^{* *}$ & Protein & Fat & Ash & Starch \\
\hline GJ \#2010 & $41.85 \pm 0.00^{\text {ba }}$ & $2.88 \pm 0.20^{\mathrm{c}}$ & $15.54 \pm 1.07^{\mathrm{a}}$ & $2.13 \pm 0.04^{\mathrm{cb}}$ & $73.63 \pm 1.10^{\mathrm{ba}}$ \\
GJ & $42.32 \pm 0.07^{\mathrm{ba}}$ & $2.89 \pm 0.11^{\mathrm{c}}$ & $14.59 \pm 2.95^{\mathrm{a}}$ & $2.07 \pm 0.07^{\mathrm{c}}$ & $70.84 \pm 5.52^{\mathrm{ba}}$ \\
GR & $38.26 \pm 0.03^{\mathrm{ba}}$ & $5.67 \pm 0.08^{\mathrm{b}}$ & $6.90 \pm 1.52^{\mathrm{c}}$ & $3.42 \pm 0.05^{\mathrm{a}}$ & $82.29 \pm 7.82^{\mathrm{a}}$ \\
WT & $23.50 \pm 0.00^{\mathrm{c}}$ & $7.74 \pm 0.16^{\mathrm{a}}$ & $10.56 \pm 1.17^{\mathrm{ba}}$ & $2.40 \pm 0.23^{\mathrm{b}}$ & $76.99 \pm 4.41^{\mathrm{ba}}$ \\
B & $52.67 \pm 0.00^{\mathrm{a}}$ & $5.90 \pm 0.01^{\mathrm{b}}$ & $12.65 \pm 2.00^{\mathrm{ba}}$ & $3.42 \pm 0.13^{\mathrm{a}}$ & $69.33 \pm 0.96^{\mathrm{b}}$ \\
\hline
\end{tabular}

** Moisture values are on wet basis

GJ \#2010= Georgia Jet clone \#2010; GJ=Georgia Jet; GR= Ginseng Red; WT=White Travis; B=Beauregard Values are expressed as Mean \pm SD. Values with different superscript letters within one column denote statistically significant differences $(\mathrm{P}<0.05)$.

The fat content varied from $6.90-15.54 \mathrm{~g} / 100 \mathrm{~g}$ dry weight. These values are expected because samples are fried products. Interestingly, cultivar GR showed a significant low fat content in its product $(6.90 \mathrm{~g} / 100 \mathrm{~g})$ compared to the other cultivars. The ash content of these samples $(2.07-3.42 \mathrm{~g} / 100 \mathrm{~g})$ is consistent with the range of $2.34-4.19 \mathrm{~g} / 100 \mathrm{~g}$ reported in previous study on sweet potato cultivars [1]. Moisture content of fried samples (wet basis) varied from 23.50 to $41.85 \mathrm{~g} / 100 \mathrm{~g}$. However, a large portion of the dry matter in the samples was comprised of starch. Highest $(82.29 \mathrm{~g} / 100 \mathrm{~g})$ and lowest $(69.33 \mathrm{~g} / 100 \mathrm{~g})$ starch values were observed in cultivars ' $G R$ ' and ' $\mathrm{B}$ ' respectively. The finding of starch as the major component in these food products is consistent with previous studies on sweet potato cultivars [1, 20]. These authors also observed wide variation in starch content among 
cultivars. Starch content of sweet potato samples in their studies ranged from 72 to $93 \%$ dry basis. This result confirmed that sweet potato is a good source of complex carbohydrate and energy.

Table 2: Total starch, resistant starch and digestible starch fractions of different cultivars of Sweet potato French fries (g/100g dry basis)

\begin{tabular}{lcll}
\hline Cultivars & \multicolumn{1}{c}{ RS } & \multicolumn{1}{c}{ DS } & \multicolumn{1}{c}{ TS } \\
\hline GJ \#2010 & $1.14 \pm 0.06^{\mathrm{cb}}$ & $72.49 \pm 1.15^{\mathrm{ba}}$ & $73.63 \pm 1.10^{\mathrm{ba}}$ \\
GJ & $1.06 \pm 0.03^{\mathrm{cb}}$ & $69.78 \pm 5.53^{\mathrm{ba}}$ & $70.84 \pm 5.52^{\mathrm{ba}}$ \\
GR & $1.37 \pm 0.11^{\mathrm{b}}$ & $80.92 \pm 7.72^{\mathrm{a}}$ & $82.29 \pm 7.82^{\mathrm{a}}$ \\
WT & $2.01 \pm 0.03^{\mathrm{a}}$ & $74.99 \pm 4.41^{\mathrm{ba}}$ & $76.99 \pm 4.41^{\mathrm{ba}}$ \\
B & $1.30 \pm 0.25^{\mathrm{cb}}$ & $68.04 \pm 1.21^{\mathrm{b}}$ & $69.33 \pm 0.96^{\mathrm{b}}$ \\
\hline
\end{tabular}

GJ \#2010= Georgia Jet clone \#2010; GJ=Georgia Jet; GR= Ginseng Red;

WT=White Travis; $\mathrm{B}=$ Beauregard

RS=Resistant starch; DS= Digestible starch; TS= Total starch

Values are expressed as Mean \pm SD. Means with different superscript letters are significantly different $(\mathrm{P}<0.05)$.

Resistant starch (RS) fraction varied significantly among cultivars with a range of 1.14 - 2.01 $\mathrm{g} / 100 \mathrm{~g}$ on dry basis (Table 2). Frying has been reported as one of the food processing methods that increase RS content in potato due to formation of amylose-lipid complexes that retard starch hydrolysis [8]. Among these studied cultivars, fried products of cultivar WT had a significant highest RS content. This finding indicates the low glycemic potential of cultivar WT products despite its high total starch content. Several studies had reported the beneficial influence of RS in starch digestion and its consequent lower glycemic responses [3-5, 8].

High values of DS fraction were observed in cultivar GR and WT. It is interesting to note that these two cultivars (GR and WT) had similarly high values of RS in comparison to the other cultivars.

Starch digestibility rate of various cultivar products as calculated from in vitro starch hydrolysis are shown on Table 3.

Table 3: In vitro starch digestibility of different cultivars of sweet potato French fries (\% dry basis)

\begin{tabular}{ccccc}
\hline Cultivars & RDS & SDS & pGI & DSI \\
\hline GJ \#2010 & $22.10 \pm 1.96^{\mathrm{a}}$ & $21.72 \pm 0.66^{\mathrm{a}}$ & $56.18 \pm 0.61^{\mathrm{ba}}$ & $30.04 \pm 3.04^{\mathrm{ba}}$ \\
GJ & $21.74 \pm 0.18^{\mathrm{a}}$ & $17.02 \pm 0.70^{\mathrm{b}}$ & $53.87 \pm 0.89^{\mathrm{cb}}$ & $30.81 \pm 2.41^{\mathrm{ba}}$ \\
GR & $18.66 \pm 1.39^{\mathrm{a}}$ & $22.33 \pm 0.71^{\mathrm{a}}$ & $54.64 \pm 0.71^{\mathrm{cb}}$ & $22.74 \pm 1.50^{\mathrm{b}}$ \\
WT & $19.68 \pm 0.17^{\mathrm{a}}$ & $21.75 \pm 0.08^{\mathrm{a}}$ & $52.16 \pm 2.41^{\mathrm{c}}$ & $25.61 \pm 1.32^{\mathrm{ba}}$ \\
B & $24.25 \pm 6.71^{\mathrm{a}}$ & $18.26 \pm 2.19^{\mathrm{b}}$ & $58.08 \pm 1.29^{\mathrm{a}}$ & $34.93 \pm 9.39^{\mathrm{a}}$ \\
\hline
\end{tabular}

GJ \#2010= Georgia Jet clone \#2010; GJ=Georgia Jet; GR= Ginseng Red; WT=White Travis; B=Beauregard $\mathrm{RDS}=$ rapidly digestible starch; SDS= slowly digestible starch; $\mathrm{pGI}=$ predicted glycemic index; SDI= starch digestion index

Values are expressed as Mean \pm SD. Means with different superscript letters are significantly different $(\mathrm{P}<0.05)$.

Values for RDS varied among cultivars but this variation was not statistically significant $(\mathrm{P}>0.05)$. The SDS was significantly higher in cultivars GR, WT and GJ \#2010 
than cultivars GJ and B $(\mathrm{P}<0.05)$. These values for RDS and SDS obtained by this method reflect the in vivo rate of starch digestion $[2,4]$.

The values for predicted glycemic index (pGI) among cultivars varied from 52.16 to $58.08 \%$. According to the classification of food glycemic index (GI), these products should not be considered high glycemic food because their GI values are less than 70\% [6]. The low to moderate GI values among these samples could be attributed to their nutritional composition and processing method. Only cultivar B (58.08 \pm 1.29$)$ and GJ \#2010 (56.18 \pm 0.61$)$ had medium pGI, others had low GI. A previous study had demonstrated the influence of frying method in lowering glycemic index of food products [8]. This present study also confirmed the fact that fried products had lower GI compared to other cooking methods like baking, steaming, microwave. Allen et al. [6] reported a medium GI in baked, steamed and microwaved sweet potato flesh (Beauregard cultivar). Englyst and Cummings [21] reported that cooking method can alter starch structure and nature resulting in significant effects on postprandial blood glucose responses. Chiu et al. [22] reported that GI is most informative in carbohydrate rich foods and consumption of food with low glycemic index value is associated with better health outcomes.

SDI, which is a measure of the relative rate of starch digestion, ranged between 22.74 to $25.61 \%$. Lower values of SDI were observed in cultivars GR and WT despite their higher TS content in comparism to other cultivars. The low RDS, high SDS fractions, high protein values and higher RS found in cultivars GR and WT compared to the other cultivars can explain the observation of low pGI and SDI. This confirms the relevance of starch fractions in food rather than the total starch. The findings also support well-known literature reports that protein, fat, and RS content in food decreases glycemic response [6, 8, 23, 24]. These food contents tend to retard starch degradation and delay gastric emptying rate in the small intestine which consequently leads to lower glycemic response and GI value of the food.

Correlation among RS, RDS, SDS, pGI and SDI are presented in Table 4. It was observed that both pGI $(\mathrm{r}=-0.52)$ and SDI $(\mathrm{r}=-0.43)$ were inversely related to RS. This correlation was only significant between pGI and RS ( $\mathrm{P}<0.05)$. As expected RS was negatively correlated to RDS but the correlation did not reach statistical significance at the $5 \%$ confidence level.

Table 4: Correlation between study parameters

\begin{tabular}{llll}
\hline Parameter & \multicolumn{1}{c}{ pGI } & SDI & RS \\
\hline RS & $-0.52^{*}$ & $-0.43^{\mathrm{NS}}$ & 1 \\
RDS & $0.55^{*}$ & $0.94^{* *}$ & $-0.37^{\mathrm{NS}}$ \\
SDS & $-0.15^{\mathrm{NS}}$ & $-0.39^{\mathrm{NS}}$ & $0.47^{\mathrm{NS}}$ \\
SDI & $0.55^{*}$ & 1 & $0.43^{\mathrm{NS}}$ \\
\hline
\end{tabular}

$\mathrm{RS}=$ resistant starch; RDS=rapidly digestible starch; SDS= slowly digestible starch;

pGI $=$ predicted glycemic index; $\mathrm{SDI}=$ starch digestion index

$\mathrm{NS}=$ correlation is not significant; $*=$ correlation is significant at 0.05 level;

$* *=$ correlation is significant at 0.01 level

Interestingly, pGI and SDI are positively correlated $(\mathrm{r}=0.55 ; \mathrm{P}<0.05)$, but their correlation with RDS fraction was found stronger with SDI $(r=0.94 ; \mathrm{P}<0.01)$ than $\mathrm{pGI}$ $(\mathrm{r}=0.55 ; \mathrm{P}<0.05)$. This finding is similar to a previous study that reported positive correlation $(\mathrm{r}=0.907 ; \mathrm{P} \leq 0.001)$ between hydrolysis index $(\mathrm{HI})$ and RDS [4]. This significant positive correlation of RDS with both pGI and SDI agrees with the suggestion of RDS as a short 
alternative for starch digestibility evaluation in food analysis [4]. It also confirmed the report that rapidly available sugars influence the relative rate of starch digestibility [1].

\section{CONCLUSION}

We conclude that fried products of Ginseng Red, Beauregard, White Travis, Georgia Jet, and Georgia Jet clone \#2010 had varied nutritional important starch fractions with low to moderate glycemic index. The starch digestibility was significantly influenced by cultivar. The resistant starch content had an inverse relationship with both predicted glycemic index and starch digestion index, while rapidly digestible starch had positive and significant influence on predicted glycemic index and starch digestion Index. Among the five studied cultivars, White Travis and Ginseng Red possess greater nutritional potentials with higher levels of beneficial starch fractions (resistant starch and slowly digestible starch), low predicted glycemic index and starch digestion Index. The low to moderate glycemic index of these food products highlights the health potentials of different sweet potato cultivars.

Competing interests: The authors declare that they have no competing interests.

Authors' Contributions: Amaka M, Odenigbo, $\mathrm{PhD}$ is the principle investigator for this research and prepared the manuscript. Jamshid Rahimi, PhD student assisted in the food processing, proximate analysis and statistical analysis. Michael Ngadi, Associate Professor is the research coordinator for the study. Arif Mustafa, Associate Professor provided the samples and assisted in some laboratory analysis. Somaia Amer, Research associate assisted in the starch digestibility analysis.

\section{REFERNCES:}

1. Ravindran V, Ravindran G, Sivakanesan R, Rajaguru SB. Biochemical and nutritional assessment of tubers from 16 cultivars of sweet potato (Ipomoea batatas L.). Journal of agricultural and food chemistry. 1995;43(10):2646-51.

2. Englyst HN, Hudson GJ. The classification and measurement of dietary carbohydrates. Food chemistry. 1996;57(1):15-21.

3. Absar N, Zaidul I, Takigawa S, Hashimoto N, Matsuura-Endo C, Yamauchi H, et al. Enzymatic hydrolysis of potato starches containing different amounts of phosphorus. Food Chemistry. 2009;112(1):57-62.

4. Rosin PM, Lajolo FM, Menezes EW. Measurement and characterization of dietary starches. Journal of Food Composition and Analysis. 2002;15(4):367-77.

5. Jansen G, Flamme W, Schüler K, Vandrey M. Tuber and starch quality of wild and cultivated potato species and cultivars. Potato research. 2001;44(2):137-46.

6. Allen JC, Corbitt AD, Maloney KP, Butt MS, Truong VD. Glycemic Index of Sweet Potato as Affected by Cooking Methods. Open Nutrition Journal. 2012;6:1-11.

7. Mahmood I, Ghugre PS, Udipi S. Resistant starch in raw and processed roots and tubers. Journal of Food Science and Technologymysore. 2006;43(3):282-5.

8. Perceval SBS, Cliff KR, Andrew OW, Henry ICL Relationship between Processing Method and the Glycemic Indices of Ten Sweet Potato (Ipomoea batatas) Cultivars Commonly Consumed in Jamaica. Journal of Nutrition and Metabolism. 2011; vol. 2011, Article ID 584832, 6 pages, 2011. 
9. Haralampu S. Resistant starch--a review of the physical properties and biological impact of RS3. Carbohydrate polymers. 2000;41(3):285-92.

10. Goñi I, Garcia-Alonso A, Saura-Calixto F. A starch hydrolysis procedure to estimate glycemic index. Nutrition Research. 1997;17(3):427-37.

11. Willett W, Manson JA, Liu S. Glycemic index, glycemic load, and risk of type 2 diabetes. The American journal of clinical nutrition. 2002;76(1):274S.

12. Brand-Miller J, Hayne S, Petocz P, Colagiuri S. Low-Glycemic Index Diets in the Management of Diabetes. Diabetes care. 2003;26(8):2261-7.

13. Jenkins DJA, Kendall CWC, Augustin LSA, Franceschi S, Hamidi M, Marchie A, et al. Glycemic index: overview of implications in health and disease. The American journal of clinical nutrition. 2002;76(1):266S-73S.

14. Zakir S, Sarwar M, Allen J, Khan MN, Butt MS. Variation in physio-chemical characteristics of some cultivars of sweet potato. Pakistan Journal of Botany. 2006;38(2):283.

15. Ludvik B, Waldhäusl W, Prager R, Kautzky-Willer A, Pacini G. Mode of action of $<\mathrm{i}>$ ipomoea batatas $</ i>$ (caiapo) in type 2 diabetic patients. Metabolism. 2003;52(7):875-80.

16. La Bonte DR, Picha DH, Johnson HA. Carbohydrate-related changes in sweetpotato storage roots during development. Journal of the American Society for Horticultural Science. 2000;125(2):200-4.

17. AOAC. Official methods of analysis: AOAC International; 1990.

18. Rashmi S, Urooj A. Effect of processing on nutritionally important starch fractions in rice varieties. International journal of food sciences and nutrition. 2003;54(1):27-36.

19. Aina AJ, Falade KO, Akingbala JO, Titus P. Physicochemical properties of twenty-one Caribbean sweet potato cultivars. International Journal of Food Science \& Technology. 2009;44(9):1696-704.

20. Zhang Z, Wheatley CC, Corke H. Biochemical changes during storage of sweet potato roots differing in dry matter content. Postharvest biology and technology. 2002;24(3):317-25.

21. Englyst HN, Cummings JH. Digestion of polysaccharides of potato in the small intestine of man. The American journal of clinical nutrition. 1987;45(2):423-31.

22. Chiu CJ, Liu S, Willett WC, Wolever T, Brand-Miller JC, Barclay AW, et al. Informing food choices and health outcomes by use of the dietary glycemic index. Nutrition Reviews. 2011;69(4):231-42.

23. Eckel RH. A new look at dietary protein in diabetes. The American journal of clinical nutrition. 2003;78(4):671-2.

24. Foster-Powell K, Holt SHA, Brand-Miller JC. International table of glycemic index and glycemic load values: 2002. The American journal of clinical nutrition. 2002;76(1):5-56. 